\title{
THE EFFECTS OF TALENT MANAGEMENT ON THE EMPLOYEE PERFORMANCE: A STUDY IN A MULTINATIONAL COMPANY IN MANUFACTURING SECTOR
}

\author{
Ece Basmaci KARALAR ${ }^{1}$, Salim ATAY ${ }^{2}$ \\ ${ }^{1}$ Marmara Üniversitesi, S.B.E., Human Resources Management and Development Yük. Lisans Prog. Mezunu \\ ${ }^{2}$ Marmara Üniversitesi, I.I.I.B.F., İşletme Bölümü, Yardmcı Doçent Dr.
}

\section{THE EFFECTS OF TALENT MANAGEMENT ON THE EMPLOYEE PERFORMANCE: A STUDY IN A MULTINATIONAL COMPANY IN MANUFACTURING SECTOR}

\begin{abstract}
Fast developing technologies and progress in organizational processes are being effective on transforming local economies into global economies. As a natural result of this, competition, where the companies fight for the best and the scarce, becomes global. At this point, "talent" has come out to be the concept the companies feel the need for the competitive advantage. Today, most of the corporate companies have started using new methods and technologies in their divisions in order to attract talent and make the most of it, since the human capital, which is unique and unlikely to be imitated, has become the most important and indispensable factor for the companies in order to win over one another. Implementation of "Talent Management" for the talented employees has become a necessity. Talent management elements such as attraction, recruitment, retention, engagement, training and development, talent audits, career planning, succession planning, performance management and total reward have been implemented in order to win the war for talent and increase employee performance. In this study, the effects of talent management on the employee performance have been investigated in an application in a multinational manufacturing company operating in Turkey. Furthermore, the relationship between employees' preferences about the talent management elements and their demographic qualifications are examined in the scope of the study.
\end{abstract}

Keywords: Talent, Talent Management, Employee Performance

\section{INTRODUCTION}

In today's competitive and globalised environment, companies need more than just capital. To ensure their sustainability and development, they have to rely on their "core competencies" which provides them with a huge competitive advantage. Having in mind that technical innovations are quickly spread through the market and they can easily be imitated, "human" together with his core competencies comes up to the stage as the most crucial factor which differentiates most among the companies. Employees from their recruitment onwards bring their talents as an added value to the companies

\author{
YETENEK YÖNETIMININ ÇALIŞAN PERFORMANSINA \\ ETKILERI: ÜRETIM SEKTÖR ÜNDE FAALIYET \\ GÖSTEREN ÇOK ULUSLU BIR ISSLETMEDE UYGULAMA
}

Özet: Hozla gelişen teknolojiler ve örgütsel süreçlerdeki ilerlemeler, yerel ekonomilerin her geçen gün küreselleşmesinde etkili olmaktadır. Firmaları kıt kaynaklarla en iyiye ulaşmak için verdikleri mücadele dünya geneline yaylmaktadır. Bu noktada rekabetçi avantajın elde edilmesi için "yetenek" firmaların ihtiyaç duyduğu bir kavram olarak ortaya çıkmaktadır. Eşsiz ve taklit edilmesi zor olan insan sermayesi şirketlerin birbirlerine üstün gelmeleri için en önemli ve vazgeçilmez bir etken halini aldı̆̆ından, günümüzde kurumsallaşmış firmalar yeteneği bünyelerine çekmek ve bu yetenekten en iyiyi elde etmek için yeni yöntemler ve teknolojiler kullanmaya başlamışlardır. Yetenekli çalışanlar için "Yetenek Yönetimi”nin uygulanması bir gereklilik haline gelmiştir. Firmalar yetenek savaşını kazanmak ve çalışan performansını artırmak için çekme, istihdam etme, elde tutma, dahil etme, eğitim ve geliştirme, yetenek denetimleri, kariyer ve yedekleme planlamasl, performans yönetimi ve toplam ödül gibi yetenek yönetimi öğelerini uygulamaktadırlar. Bu çalışmada, yetenek yönetimi uygulamalarının çalışan performansı üzerindeki etkileri Türkiye'de üretim sektöründe faaliyet gösteren çok uluslu bir firmada araştırılmıştır. Ayrıca çalışanların yetenek yönetimi araçları konusundaki tercihlerinin demografik özelliklerle nasıl şekillendiği çalışma kapsamında incelenmiştir.

Anahtar Kelimeler: Yetenek, Yetenek Yönetimi, Çalışan Performanst

with them. At this very point after recruiting the employees with their existing talents, the companies are liable to make use of these talents besides trying to develop and keep these talents in-house. Winners in the competition for scarce talent are finding new ways to reward employees when they acquire added value, recognizing it before a competitor does, and creating a better workforce deal [1]. Briefly, talent management practices have developed and adapted throughout the years in response to many changes in the workplace, from the industrial revolution and the rise of labor unions, to affirmative action, globalization, and outsourcing, to name just a few [2]. 
To attract and retain key talent, more and more companies have started to implement talent management strategies for their current and future success. Talent management strategies form a from-cradle-to-the-grave perspective starting from the selection of the right person for the right task and expanding its boundaries to detect the key talent within the company, to keep and develop this talent. While the recruitment of individuals is important to the long term success of all organizations, the retention of the current employees and their ongoing development has become even more critical. To be successful, organizations must consider nurturing and developing all the talent within the organization [3]. Otherwise, the organization is likely to lose the employees with high potential, who will take all the talent and knowledge with them, which will result in a talent vacancies and these vacancies will be difficult to be replaced.

As the one of the main objectives of talent management is to enable employees' performance as well as to increase their organizational commitment and motivation, it is crucial to determine the effective talent management tools to provide employee performance. Therefore, the effects of talent management on employee performance will be examined in the scope of this research.

\section{TALENT AND TALENT MANAGEMENT}

Talent is any recurring pattern of thought, feeling, or behavior that can be productively applied [4]. Talent may even include the skills and capabilities of people in other organizations-people nominally working on the other side of organization boundaries that future business needs may require crossing in order to form extended enterprises [5].
Among all the factors that could influence the effectiveness of organizations in the future, the foremost driver is talent [4]. The value of hard assets has declined relative to the value of a company's intangible assets assets such as proprietary intellectual capital, winning brands, and innovative ideas in the accession process to Information Age from Industrial Age. Underpinning all of these intangibles is talent [6].

In many of the world's fast-growing economies, it may easier to access money and technology than good people. This means competitive advantage belongs to companies that know how to attract, select, deploy and develop talent. Since the ultimate resource of all information, service and knowledge-added is people, the only way to be successful is to manage people effectively. Here, at this very point, the most crucial thing appears to be the management of talent in an efficient manner by selecting, developing and deploying talent [7].

The talent management system (TMS) is an effective tool for creating a symbiotic relationship between talent and the organization to dramatically accelerate performance improvements. The TMS is a distinct function within the organizational management system devoted exclusively to attracting, keeping, managing and identifying talent [8].

Talent management is about how organizations attract, select, retain, develop and align the right people, in the right roles, at the right time - to deliver their strategy now and in the future [9]. Talent management starts with the business strategy and what it signifies in terms of the talented people required by the organization. Ultimately, its aim is to develop and maintain a talent pool consisting of a skilled, engaged and committed workforce. Its elements are described in Figure.1.

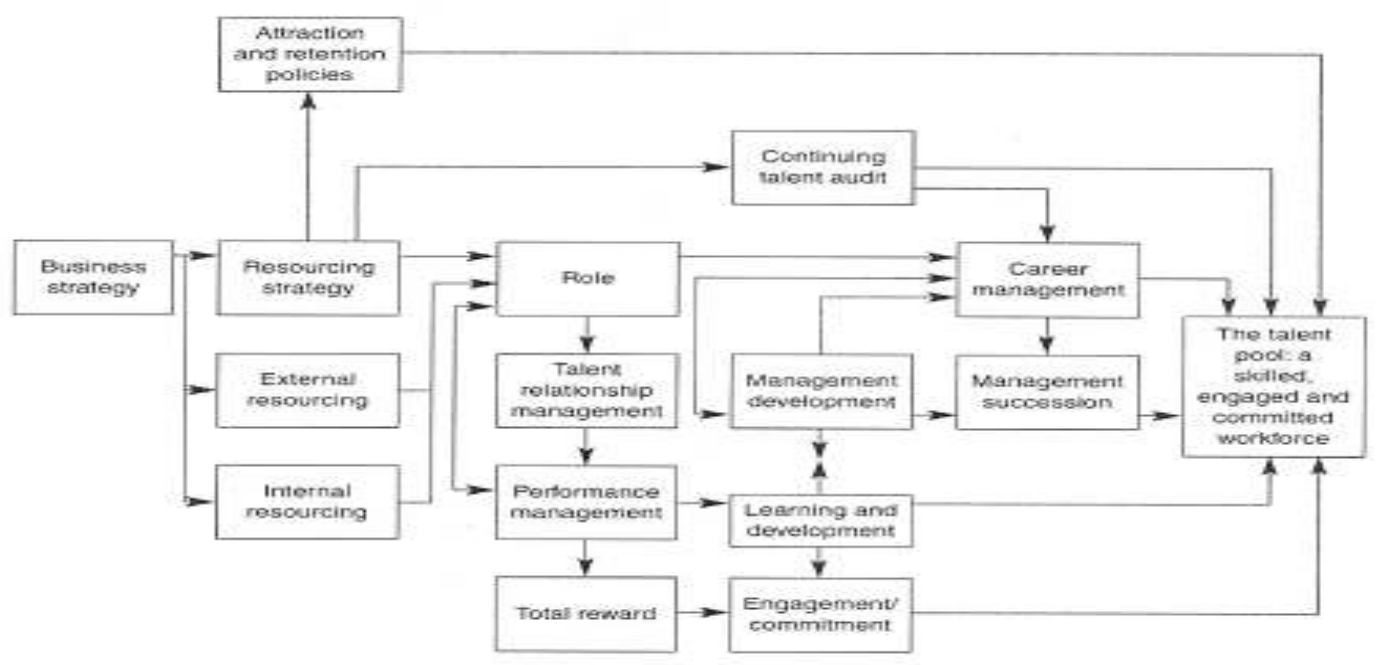

Figure.1. The Elements of Talent Management

Source: Armstrong, M. (2006). Handbook Human Resource Practice. 10th Ed. London: GBR, Kogan Page, 391 [10]. 
Being one of the most effective tools for increasing employer's interest and eagerness, talent management is increasingly being used mostly in corporate organizations, already having realized the need for a full-fledged talent management system including succession planning, career management, performance appraisal, training and development, retention and attraction strategies, talent audits, etc.

Resourcing strategy, retention and recruitment, talent audit, role development, talent relationship management, performance management /appraisal, total reward [11], training and development, career development are the main elements of talent management.

\section{PERFORMANCE AND PERFORMANCE MANAGEMENT}

Performance is essentially what an employee does or does not do. Performance of employees that affects how much they contribute to the organization could include quality of output, quantity of output, timeliness of output, presence at work and cooperativeness. Though there might be specific job criteria for each specific job, above-mentioned elements are common to most. [12]

As Williams points out, there are at least three different models of performance management (PM); PM as a system for managing organizational performance; $\mathrm{PM}$ as a system for managing employee performance; PM as a system for integrating the management of organizational and employee performance [13]. Performance management [or appraisal] processes provide a means of building relationships with people, identifying talent and potential, planning learning and development activities and making the most of the talent possessed by the organization [10].

\section{RELATIONSHIP MANAGEMENT PERFORMANCE}

\section{BETWEEN TALENT AND EMPLOYEE}

Talent management is not restricted to only one HR function, but is comprehensive since it embraces a multiple set of HR functions such as recruitment, succession planning, career development, training and development, performance management, etc. in order to ensure that the organization attracts, recruits, retains and engages its talented employees. Due to the fact that people constitute the core of each corporate structure as well as the most vital tool for gaining competitive advantage in a business environment, management of talent, which refers to the people in this context, is crucial in order to make the most of the talent possessed by the organization.
Moreover, the HR processes that need to be considered in conjunction with the talent program include performance management which is a core activity for talent spotting and development; its level of sophistication in discriminating between high, good, average and poor performance is vital to success of talent management [14].

Talented people, no matter which title they have in an organizational structure, would like to be realized and appreciated. They would like to have their performance measured and get feedback on what they are doing well and what sides they should work on developing. They expect the organization to appraise their performance regularly either through supervisor appraisals, customer appraisals, subordinate or self-appraisals, etc. Following a full-fledged performance appraisal, the employer gives feedback, offers development programs or financial and non-financial rewards which contributed to the increase in the performance of the employees. Furthermore, the economic benefits of talent management are demonstrated at the individual level. "A" players, or the best 10-15 percent performers of an organization, have improvements in performance output, ranging from 19 to 120 percent, depending on the complexity of the job [15].

It may be true to suggest that being an element of talent management systems, performance appraisal is a circular process, which has no end. Starting with a formal appraisal process followed by feedback, training and development opportunities and various rewards (such as compensation, promotion, recognition, appreciation, etc.) offered to the talented employee, whose performance will be given a pace as a result of these motivating tools. In other words, it can be suggested that performance appraisal is a complex system leading to feedback and development in order to make the best of people in an organization.

Having the human being as their core element, performance management and talent management are mutually-inclusive processes, where the aim is to achieve development both for the employee and the organization and to obtain improved business results.

An often-cited study by Mark Huselid shows that a standard deviation increase in high-performance talentmanagement practices is associated with enormous economic returns which are significant indicators of organization and employee performance. The selected companies, in the top 15 percent of all those in Huselid's study in terms of their use of high-performance talentmanagement practices, were associated with some financial advantages such as "a 7 percent decrease in turnover", "an increase of $\$ 3800$ in profits per employee", "\$27.000 in sales per employee" and "an increase of \$ 18.600 in market value per employee" [16]. 
In conclusion, the use of talent management systems is one of the factors contributing to the increased productivity of the employees through the enhancement of their interest and eagerness towards work. Therefore, employees in the relevant sectors should identify and apply required methods in order to motivate employees towards the achievement of higher level of interest and eagerness, which are the prerequisites of higher performance.

\section{METHODOLOGY}

In today's organizations, it is required for the employees to be analyzed by their managers. Moreover, it is also vital to identify the talent management tool(s) to be utilized in different groups of employees to increase their performance. Demographics such as gender, age, marital status, level of education and even the title at work have an effect on the variety; frequency, type and time of use as far as talent management tools are concerned. Due to this very reason, it is crucial to whom, how often, to which extent and when these talent management tools will be used. Taking all these factors into consideration, it can be inferred that if a talent management system that is considered to be effective on the performance of the employees in a workplace is formed, employees in that workplace can be motivated towards the demanded direction.

The goal of this study is to explore the effect of talent management and its tools on the performance of the employees working for an American multinational company operating in metal packaging sector in Turkey (herein after will be referred to as The company) and to determine which tools are more effective on the performance of the above-mentioned employees.

"Do talent management tools have an effect on employee performance in multinational companies in manufacturing sector, if so, which tools are more effective on the employees?" makes up the statement of the problem in the study.

Questionnaire, developed in line with the goal of the research, was used to collect data [17]. The questionnaire is composed of 3 parts. In the first part, there are 6 questions regarding socio-demographic characteristics of the employees (gender, age, and marital status, level of education, seniority and title). In the second part, there are 16 statements, which define talent management preferences of the employees. These statements were graded using a 5-point Likert scale. These points in the scale are "Strongly Agree" (5), "Agree" (4), "Uncertain" (3), "Disagree" (2) and "Strongly Disagree" (1).126 In the third and last part of the questionnaire, a list of 12 talent management tools was given. The audience were asked to give a number to each item according to the degree of importance of each item in terms of their effect on performance ranging from 12 (most effective) to 1 (least effective).

The sampling of the study consists of the total population of the Turkish branch of a multinational packaging company. The confidence level of the sample has been determined as $\% 95$. Moreover, sampling error was $\% 10$ and $p$ value was 0,8 [18]. Therefore, sixty-two people working for the above-mentioned company were asked to fill out the questionnaire. Questionnaires were collected two days after they were distributed.

In this study the universe consists of employees having one of these titles: officer/technician, executive, specialist, assistant specialist, manager, high-level manager.

After the formation of the questionnaire, a pilot test was applied on a group of 10 employees, all of whom were selected taking their socio-demographical characteristics into consideration to ensure whether the questions were understandable for the employees. The open-ended questions "What do you think the most crucial factors having an effect on the performance is?", "How do you understand that the talents are recognized?" were addressed to the population to whom this pre-test was employed. The talent management tools were derived from the responses to these questions and it was converted to be a close-ended question in the form of "You are requested to rank below-listed talent management tools from most effective to least effective in terms of their effect on the performance", which makes up the third and last part of the questionnaire.

\section{RESULTS AND DISCUSSION}

According to the demographic qualifications, $27.42 \%$ of the participants are female, whereas $72.58 \%$ of them are male, which proves a male majority in the population of the research. While observing the fact that frequency of male participants is higher, it should not be ignored that the employees in the company which is representative of the sector are mostly male. When age distribution of the participants was analyzed, it was detected that $41.94 \%$ of the participants are between 31 40 years of age. This percentage is followed by $35.48 \%$, which is composed of the participants between 21-30 years of age. The lowest percentage belongs to the participants between $16-20$ is $1.61 \%$. $32.26 \%$ of the participants are single, while 64.52 of them are married. $29.03 \%$ of the employees had graduated from high school. The ones having graduate degree follows them with $22.58 \%$. $20.97 \%$ of the participants graduated from college, while $11.29 \%$ of them have graduate degrees. The ones having graduated from primary school was observed to be $6.45 \%$ of the total sampling group. The largest slice in the pie chart belongs to the employees whose seniority in the company is over 10 years with 
$29,03 \%$. The second highest frequency belongs to the employees working for the Company for a time period between 3 to 5 years with $24.19 \%$. $19.35 \%$ of the participants have been working for the Company for 5 to 8 years, whereas $16.13 \%$ of them have been working there for 1 to 3 years. The employees who have been working there for 8 to 10 years make up $11.29 \%$ of the population the highest percentage of the employees are officer or technician with $41.94 \% .27 .42 \%$ of the participants said they are executive, while $12.90 \%$ indicated that they are specialist. Managers form $8.06 \%$ of the population and high-level managers make up $3.23 \%$ of the population.

In Table.1, it can be observed that the percentages of employees' agreement with the relevant talent management tools (strongly agree and agree) are high. Especially Statement no. 1 which is "Financial rewards (wage, premium, bonus) are very important for the employees" took the highest percentage of "Strongly agree" response, with $62.9 \%$ which is the highest percentage among the others. "Strongly agree" response given to statement no. 7 which is "Appreciation of the successful employees by their managers increases their performance." is the second highest percentage with $58.1 \%$ as far as "Strongly agree" response is concerned. The third most preferred "Strongly agree" response is given to statement no. 6 which is "Performance enhancement should be achieved through giving opportunity to promote to the talented employees." with $46.8 \%$.

The result of crosstab and chi-square analysis according to gender shows that no significant difference was observed statistically in $95 \%$ reliability. It was detected that talent management statements have parallel effects on the performance of both men and women.

The employees' responses according to age variable has no significant difference between these variables was observed statistically in $95 \%$ reliability except for Statement no.1 which is "Financial rewards (wage, premium, and bonus) are very important for the employees." A significant difference (p: 0,047<0.05) was analyzed between the level of responses to Statement no. 1 and age variable. It was identified that talent management statements (except for Statement no. 1) have a parallel effect on all age groups.

When the results of crosstab and chi-square analysis of the employees' responses according to marital status variable were searched through, no significant difference was observed statistically in $95 \%$ reliability. It was detected that talent management statements have a parallel effect on the performance of both males and females.

The employees' responses according to educational level variable have no significant difference except for Statements no. 4, 8, 9 and 10.

A significant difference for educational level variable (p: 0,041<0.05) was observed among the level of responses to Statement no. 4, which is "An increase in employee performance will be observed if managers recognize the talents of the employees and direct them to the right tasks".

A significant difference for educational level variable (p: $0,020<0.05)$ was observed among the level of responses to Statement no. 8, which is "Giving authority and responsibility to a talented employee, and providing him with flexibility and autonomy have positive effects on employee performance".

A significant difference for educational level variable (p: $0,001<0.05)$ was observed among the level of responses to Statement no. 9, which is "In order to ensure high level of performance of the employees, it is important for them to be able to have a voice in corporate decision-making process".

A significant difference for educational level variable (p: $0,013<0.05$ ) was observed among the level of responses to Statement no. 10, which is "Assistance of the managers to the employees in their career planning gives rise to employee performance".

It was identified that rest of the statements had a parallel effect on the performance of the groups belonging to one of the five groups each of which representing a separate level of education.

When the results of crosstab and chi-square analysis of the employees' responses according to seniority variable were searched through, no significant difference was observed statistically in $95 \%$ reliability except for the Statement no.3, which is "Measurement of employee performance and facilitation of feedback regarding its results are effective on the increase of performance". A significant difference among the level of responses to the Statement no. 3 (p: $0,001<0.05$ ) was identified as far as seniority variable is concerned. It was identified that rest of the statements had a parallel effect on the performance of the groups having been formed in accordance with their seniority. 
Table.1. Frequency and Percentages of the Responses Given by the Employees to the Questions in the Part 2 of the Questionnaire

\begin{tabular}{|c|c|c|c|c|c|c|c|c|c|c|c|c|}
\hline \multirow{2}{*}{$\begin{array}{l}\text { 2nd Part } \\
\text { No of statement }\end{array}$} & \multicolumn{2}{|c|}{$\begin{array}{l}\text { Strongly } \\
\text { agree }\end{array}$} & \multicolumn{2}{|c|}{ agree } & \multicolumn{2}{|c|}{ uncertain } & \multicolumn{2}{|c|}{ disagree } & \multicolumn{2}{|c|}{$\begin{array}{l}\text { Strongly } \\
\text { disagree }\end{array}$} & \multicolumn{2}{|c|}{ Missing data } \\
\hline & $\mathbf{f}$ & $\%$ & $\mathbf{f}$ & $\%$ & f & $\%$ & $\mathbf{f}$ & $\%$ & f & $\%$ & f & $\%$ \\
\hline $\begin{array}{l}\text { 1. Financial rewards (wage, } \\
\text { premium, and bonus) are very } \\
\text { important for the employees. }\end{array}$ & 39 & 62,9 & 19 & 30,6 & 1 & 1,6 & 3 & 4,8 & 0 & 0 & 0 & 0 \\
\hline $\begin{array}{l}\text { 2. If the individual goals are in line } \\
\text { with the corporate goals, this will } \\
\text { increase the productivity of the } \\
\text { employees. }\end{array}$ & 18 & 29,0 & 27 & 43,5 & 9 & 14,5 & 5 & 8,1 & 3 & 4,8 & 0 & 0 \\
\hline $\begin{array}{l}\text { 3. Measurement of employee } \\
\text { performance and facilitation of } \\
\text { feedback regarding its results are } \\
\text { effective on the increase of } \\
\text { performance. }\end{array}$ & 18 & 29,0 & 32 & 51,6 & 4 & 6,5 & 6 & 9,7 & 1 & 1,6 & 1 & 1,6 \\
\hline $\begin{array}{l}\text { 4. An increase in employee } \\
\text { performance will be observed if } \\
\text { managers recognize the talents of the } \\
\text { employees and direct them to the } \\
\text { right tasks. }\end{array}$ & 20 & 32,3 & 37 & 59,7 & 1 & 1,6 & 3 & 4,8 & 1 & 1,6 & 0 & 0 \\
\hline $\begin{array}{l}\text { 5. Overlapping corporate culture and } \\
\text { values, and individual ones lead to } \\
\text { higher motivation of the employee. }\end{array}$ & 17 & 27,4 & 28 & 45,2 & 9 & 14,5 & 8 & 12,9 & 0 & 0 & 0 & 0 \\
\hline $\begin{array}{l}\text { 6.Performance enhancement should } \\
\text { be achieved through giving } \\
\text { opportunity to promote to the } \\
\text { talented employees. }\end{array}$ & 29 & 46,8 & 30 & 48,4 & 1 & 1,6 & 0 & 0 & 1 & 3,2 & 0 & 0 \\
\hline $\begin{array}{l}\text { 7. Appreciation of the successful } \\
\text { employees by their managers } \\
\text { increases their performance. }\end{array}$ & 36 & 58,1 & 23 & 37,1 & 0 & 0 & 3 & 4,8 & 0 & 0 & 0 & 0 \\
\hline $\begin{array}{l}\text { 8. Giving authority and responsibility } \\
\text { to a talented employee, and providing } \\
\text { him with flexibility and autonomy } \\
\text { have positive effects on employee } \\
\text { performance. }\end{array}$ & 21 & 33,9 & 31 & 50,0 & 4 & 6,5 & 6 & 9,7 & 0 & 0 & 0 & 0 \\
\hline $\begin{array}{l}\text { 9. In order to ensure high level of } \\
\text { performance of the employees, it is } \\
\text { important for them to be able to have } \\
\text { a voice in corporate decision-making } \\
\text { process. }\end{array}$ & 12 & 19,4 & 25 & 40,3 & 14 & 22,6 & 10 & 16,1 & 1 & 1,6 & 0 & 0 \\
\hline $\begin{array}{l}\text { 10. Assistance of the managers to the } \\
\text { employees in their career planning } \\
\text { gives rise to employee performance. }\end{array}$ & 13 & 21,0 & 38 & 61,3 & 9 & 14,5 & 1 & 1,6 & 0 & 0 & 1 & 1,6 \\
\hline $\begin{array}{l}\text { 11. Providing development of the } \\
\text { employees for the future staffing } \\
\text { needs, corporate succession planning } \\
\text { leads to higher level of employee } \\
\text { productivity }\end{array}$ & 6 & 9,7 & 27 & 43,5 & 22 & 35,5 & 6 & 9,7 & 1 & 1,6 & 0 & 0 \\
\hline $\begin{array}{l}\text { 12. Recognition of talents is } \\
\text { important in order to provide an } \\
\text { increase in employee performance. }\end{array}$ & 20 & 32,3 & 35 & 56,5 & 2 & 3,2 & 4 & 6,5 & 0 & 0 & 1 & 1,6 \\
\hline $\begin{array}{l}\text { 13. If the employees are given the } \\
\text { opportunity to develop their talents, } \\
\text { their productivity will increase. }\end{array}$ & 26 & 41,9 & 33 & 53,2 & 1 & 1,6 & 2 & 3,2 & 0 & 0 & 0 & 0 \\
\hline $\begin{array}{l}\text { 14. Working for a well-positioned } \\
\text { company in the relevant sector leads } \\
\text { to an increase in employee } \\
\text { performance. }\end{array}$ & 18 & 29,0 & 30 & 48,4 & 4 & 6,5 & 8 & 12,9 & 2 & 3,2 & 0 & 0 \\
\hline $\begin{array}{l}\text { 15. Difficult tasks intended to develop } \\
\text { talents of the employees have a } \\
\text { positive effect on employee } \\
\text { performance. }\end{array}$ & 9 & 14,5 & 27 & 43,5 & 10 & 16,1 & 14 & 22,6 & 2 & 3,2 & 0 & 0 \\
\hline $\begin{array}{l}\text { 16. The awareness of the employees } \\
\text { regarding their contribution to the } \\
\text { company increases their motivation. }\end{array}$ & 18 & 29,0 & 38 & 61,3 & 3 & 4,8 & 3 & 4,8 & 0 & 0 & 0 & 0 \\
\hline AVERAGE & 20 & 32,26 & 30 & 48,39 & 6 & 9,48 & 5 & 8,27 & 1 & 1,35 & & 0,26 \\
\hline
\end{tabular}


When the results of crosstab and chi-square analysis of the employees' responses according to title variable were searched through, no significant difference was observed statistically in $95 \%$ reliability except for the Statement no. 9, which is "In order to ensure high level of performance of the employees, it is important for them to be able to have a voice in corporate decisionmaking process". A significant difference among the level of responses to the Statement no.9 (p: $0,045<0.05$ ) was identified as far as title variable is concerned. It was identified that rest of the statements had a parallel effect on the performance of the groups having been formed in accordance with their titles at the workplace

When we look at the socio-demographical variables, it can be inferred that Statement no. 9, which is "In order to ensure high level of performance of the employees, it is important for them to be able to have a voice in corporate decision-making process." has displayed a significant difference with $95 \%$ probability both for "title" and "level of education".

Table.2. The Distribution of the Most Preferred Talent Management Tools Which Were Given 12 Points

\begin{tabular}{|c|c|c|c|}
\hline \multicolumn{2}{|c|}{ Talent management tools } & \multirow{2}{*}{$\begin{array}{c}\begin{array}{c}\text { Frequency } \\
\text { (n) }\end{array} \\
2\end{array}$} & \multirow{2}{*}{$\begin{array}{c}\begin{array}{c}\text { Percentage } \\
(\%)\end{array} \\
3,2\end{array}$} \\
\hline $\mathrm{a}$ & Performance Appraisal & & \\
\hline $\mathrm{b}$ & Succession Planning & 1 & 1,6 \\
\hline $\mathrm{c}$ & Feedback & 1 & 1,6 \\
\hline $\mathrm{d}$ & Flexibility and Autonomy & 1 & 1,6 \\
\hline $\mathrm{e}$ & Financial Reward & 27 & 43,5 \\
\hline$f$ & Career Planning & 3 & 4,8 \\
\hline $\mathrm{g}$ & $\begin{array}{l}\text { Training and Development } \\
\text { Opportunities }\end{array}$ & 2 & 3,2 \\
\hline $\mathrm{h}$ & $\begin{array}{l}\text { Authority and } \\
\text { Responsibility }\end{array}$ & 3 & 4,8 \\
\hline $\mathrm{i}$ & Recognition & 4 & 6,5 \\
\hline $\mathrm{j}$ & $\begin{array}{l}\text { Overlapping individual and } \\
\text { corporate cultures }\end{array}$ & 10 & 16,1 \\
\hline $\mathrm{k}$ & Career Development & 5 & 8,1 \\
\hline 1 & Appreciation & 3 & 4,8 \\
\hline \multicolumn{2}{|c|}{ Total } & 62 & 100 \\
\hline
\end{tabular}

When Table. 2 was analyzed in order to see the distribution of talent management tools which were most preferred by the respondents having graded these items with 12 points, it was observed that "Financial Rewards" are the most preferred talent management tool with 43.5\%, while "Succession Planning", "Feedback", "Flexibility and Autonomy" are the least preferred tools all with $1.6 \%$.
Table.3. The Distribution of the Second Most Preferred Talent Management Tools Which Were Given 11 Points

\begin{tabular}{|c|c|c|c|}
\hline \multicolumn{2}{|c|}{ Talent management tools } & \multirow{2}{*}{$\begin{array}{c}\begin{array}{c}\text { Frequency } \\
\text { (n) }\end{array} \\
3\end{array}$} & \multirow{2}{*}{$\begin{array}{c}\begin{array}{c}\text { Percentage } \\
(\mathbf{\%})\end{array} \\
4,8\end{array}$} \\
\hline a & Performance Appraisal & & \\
\hline b & Succession Planning & 2 & 3,2 \\
\hline $\mathrm{c}$ & Feedback & 4 & 6,5 \\
\hline d & Flexibility and Autonomy & 3 & 4,8 \\
\hline e & Financial Reward & 9 & 14,5 \\
\hline$f$ & Career Planning & 3 & 4,8 \\
\hline $\mathrm{g}$ & $\begin{array}{l}\text { Training and Development } \\
\text { Opportunities }\end{array}$ & 6 & 9,7 \\
\hline $\mathrm{h}$ & $\begin{array}{l}\text { Authority and } \\
\text { Responsibility }\end{array}$ & 8 & 12,9 \\
\hline $\mathrm{i}$ & Recognition & 1 & 1,6 \\
\hline $\mathrm{j}$ & $\begin{array}{l}\text { Overlapping individual and } \\
\text { corporate cultures }\end{array}$ & 3 & 4,8 \\
\hline $\mathrm{k}$ & Career Development & 4 & 6,5 \\
\hline 1 & Appreciation & 15 & 24,2 \\
\hline \multicolumn{2}{|c|}{ Total } & 61 & 98,4 \\
\hline
\end{tabular}

When Table. 3 was analyzed in order to see the distribution of talent management tools which were the second most preferred by the respondents having graded these items with 11 points, it can be observed that "Recognition" comes out to be the most-preferred tool with 24.2\%, whereas "Recognition" and "Succession Planning" tools are the least-preferred tools, respectively with $1.6 \%$ and $3.2 \%$.

Table.4. The Distribution of Talent Management Tools Preferred at the Third Rank with 10 Points

\begin{tabular}{|c|c|c|c|}
\hline \multicolumn{2}{|c|}{ Talent management tools } & \multirow{2}{*}{$\begin{array}{c}\begin{array}{c}\text { Frequency } \\
\text { (n) }\end{array} \\
15\end{array}$} & \multirow{2}{*}{$\begin{array}{c}\begin{array}{c}\text { Percentage } \\
(\mathbf{\%})\end{array} \\
24,2\end{array}$} \\
\hline $\mathrm{a}$ & Performance Appraisal & & \\
\hline $\mathrm{b}$ & Succession Planning & 1 & 1,6 \\
\hline $\mathrm{c}$ & Feedback & 2 & 3,2 \\
\hline d & Flexibility and Autonomy & 3 & 4,8 \\
\hline e & Financial Reward & 4 & 6,5 \\
\hline $\mathrm{f}$ & Career Planning & 1 & 1,6 \\
\hline g & $\begin{array}{l}\text { Training and Development } \\
\text { Opportunities }\end{array}$ & 5 & 8,1 \\
\hline h & $\begin{array}{l}\text { Authority and } \\
\text { Responsibility }\end{array}$ & 7 & 11,3 \\
\hline $\mathrm{i}$ & Recognition & 7 & 11,3 \\
\hline $\mathrm{j}$ & $\begin{array}{l}\text { Overlapping individual and } \\
\text { corporate cultures }\end{array}$ & 1 & 1,6 \\
\hline $\mathrm{k}$ & Career Development & 6 & 9,7 \\
\hline 1 & Appreciation & 10 & 16,1 \\
\hline \multicolumn{2}{|c|}{ Total } & 62 & 100 \\
\hline
\end{tabular}


When Table. 4 was analyzed in order to see the distribution of talent management tools which were preferred at the third rank by the respondents having graded these items with 10 points, it was observed that "Performance appraisal" constitutes the most preferred tool with $24.2 \%$, while "Succession Planning", "Career Planning" and "Overlapping Individual and Corporate Culture" are the least preferred tools with $1.6 \%$.

Table.5. Reliability Analysis

\begin{tabular}{cc}
\hline Cronbach's Alpha & N of Items \\
\hline 0,846 & 16
\end{tabular}

As can be inferred from Table.5, Cronbach Alpha coefficient is 0.846 , a value which is bigger that 0.7 . It was identified that the data collecting instrument is reliable.

\section{CONCLUSION}

Talent management is a complex system including the functions of attraction, selection, recruitment, retention, learning and development, performance management, career development, succession planning. It is increasing being used by the corporate organizations having realized the fact that competitive advantage can only be attained through human capital. Being able to keep talented people appears to be as import as attracting and recruiting them, which displays the importance of talent management processes.

When the most preferred talent management tools were listed, it was seen that financial rewards outstands. It can be inferred that the value attributed to this tool by the employees is meaningful. While "Financial Rewards" takes the first rank in the list by 12 points, "Appreciation", "Overlapping corporate and individual goals", "Performance Management", "Authority and Responsibility" and "Recognition" follows this tool. In addition to these tools mentioned, "Career development" and "training and development facilities" have been detected to appear as subsidiary tools supporting the primary ones above and their usage in talent management has appeared to be a must.

To look at the overall picture, as a result of the analysis, it was observed that the ratio of the employees who believes that the talent management tools have a positive effect on their performance is $80.65 \%$, whereas the ratio is $9.62 \%$ for those who do not believe in the effect of talent management tools on performance. $9.48 \%$ of those who took part in the survey are not certain on whether this effect exists or not.
It may be suggested that organizations should have talent management systems in order to have an increase in employee performance. The tools of talent management include "Financial Rewards", "Appreciation", "Overlapping corporate and individual goals", "Performance Management", "Authority and Responsibility", "Recognition" "Succession planning", "Feedback", "Flexibility and autonomy" and "Career planning" as suggested by the employees and supported by the literature review. Following the ratios derived from the data, it is clearly seen that financial rewards are the much-preferred tools of talent management according to the employees, while appreciation and overlapping corporate and individual goals takes the second and third rank, respectively.

On the other hand, it can be seen that flexibility and autonomy have not been highly rated by the respondents, which may be the result of the fact that Turkey has a collectivist culture, unlike individualist cultures, whose people cherish autonomy and flexibility. Although the Company is an American Company, the employees are Turkish citizens belonging to the very collectivist culture.

Due to the cultural differences within a company and an organization, due to the segmental differences among the employees, these differences should be taken into consideration while establishing a talent management system in an organization.

The other issues at stake are that the results may subject to change if the questionnaire is applied on other employees in other cultures. The results may subject to change if the questionnaire is applied on other employees in other cultures. For example, if the sampling group had been consisted of the employees of the same company, but this time its branch in France, a country with individualist culture and higher life standards leading to high level of prosperity may have been the case that recognition, autonomy, succession planning, etc. may have been highly rated, since the people in individualist cultures attribute a great importance to those kind of talent management tools involving self-realization and self-actualization motives. Therefore, it may be suggested that future studies could enlarge the scope of the study by covering more companies from the same segment or sectors (i.e. service sector) as well as the variety of the sampling group in order to avoid overgeneralization errors. 


\section{REFERENCES}

[1] Zingheimr, P.K. \& Schuster, J.R. (1999). Dealing With Scarce Talent: Lessons from the Leading Edge. Compensation Benefits Review, 31(2), 36-44.

[2] Frank, D.F. \& Taylor, R.C. (2004). Talent Management: Trends That Will Shape the Future. Human Resource Planning, 27(1), 33-41.

[3] Buhler, P.M. (2007). Managing in the New Millennium: Developing the Talent Within. Supervision, 68(5), 20-24.

[4] Buckingham, M. \& Donald, O.C. (2002). Now, Discover Your Strenghts. New York:: Simon\&Schuster.

[5] Sears, D. (2002). Successful Talent Strategies: Achieving Superior Business Results Through Market-Focused Staffing. Saranac Lake, NY: AMACOM.

[6] (2001). The War for Talent, Organization and Leadership Practice. New York:: McKinsey\&Company.

[7] Gubman, E.L. (1998). The Talent Solution: Align Strategy \& People to Achieve Extraordinary Results, Blacklick, $\mathrm{OH}$ : McGraw-Hill Professional Book Group.

[8] Kurtuluş, E. (2006). İșe Alım Sürecinde Yetenek ve Kişilik Testlerinin Önemi: Bir İlaç Firmasında Satış Temsilcileri Üzerine Bir Araştırma. Yayınlanmamış Yüksek Lisans Tezi, Marmara Üniversitesi.

[9] Ed, M.; Handfield-Jones, H. \& Axelrod, B. (2001). The War for Talent. Excerpt from the War for Talent. (http://www.businessweek.com/careers/content/dec2001/ ca20011212_2256.htm). [27.06.2008].

[10] Armstrong, M. (2006). Handbook Human Resource Practice. 10th Ed. London: GBR, Kogan Page.

[11] Mathis, R.L. \& Jackson, J.H. (1991). Performance Management and Appraisal, Human Resource Management. California: South-Western College Publishing.

[12] (2005). Talent Management: What the Best Organizations Actually Do. Hay Group Working Paper. (http://www.haygroup.com/downloads/ie/

Talent_Management_working_paper.pdf).[24.06.2008].

[13] Fletcher, C. (2001). Performance Appraisal and Management: The Developing Research Agenda. Journal of Occupational and Organizational Psychology, 74(4), 473-487.

[14] Garrow, V. \& Hirsh, W. (2008). Talent Management: Issues of Focus and Fit, Public Personnel Management, Winter, 37(4), 389-402.
[15] Hunter, J.E.; Schmidt, F.L. \& Judiesch, M.K. (1990). Individual Differences in Output Variability as a Function of Job Complexity. Journal of Applied Psychology, 75(1), $28-42$.

[16] Heinen, J.S. \& O'Neill, C. (2004). Managing Talent to Maximize Performance. Employment Relations Today; Summer, 31(2), 67-82.

[17] Nas, T. (2006). Sağlık Örgütlerinde Ödüllendirme Sistemlerinin Performans Üzerine Etkisi ve Bir Uygulama. Yayınlanmamış Yüksek Lisans Tezi. Gazi Üniversitesi

[18] Yazıcıoğlu, Y. \& Erdoğan, S. (2004), SPSS Uygulamal Bilimsel Araştırma Yöntemleri. Ankara: Detay Yayıncılık.

Ece Basmacı KARALAR (ekaralar@dogus.edu.tr) is an instructor of English in Degree English Unit at Doğuş University. She had her BA in Translation\&Interpreting at Boğaziçi University and MA in Human Resources Management and Development at Marmara University. Her research areas are industrial\&organizational psychology and learning\&behavior.

Salim ATAY (salim@marmara.edu.tr) is an Assistant Professor in Faculty of Economic and Administrative Sciences, Department of Management and Organization, Marmara University. His research areas are organizational behavior, work psychology, leadership and cognitive style. 